Tourist Motives and Destination Image Perception:

The Case of Sri Lanka as a Tourist Destination

By

Wijethunga Mudiyanselage Heshani Uthpala

Wijethunga

M.Sc.

2015 


\section{Tourist Motives and Destination Image Perception:}

\section{The Case of Sri Lanka as a Tourist Destination}

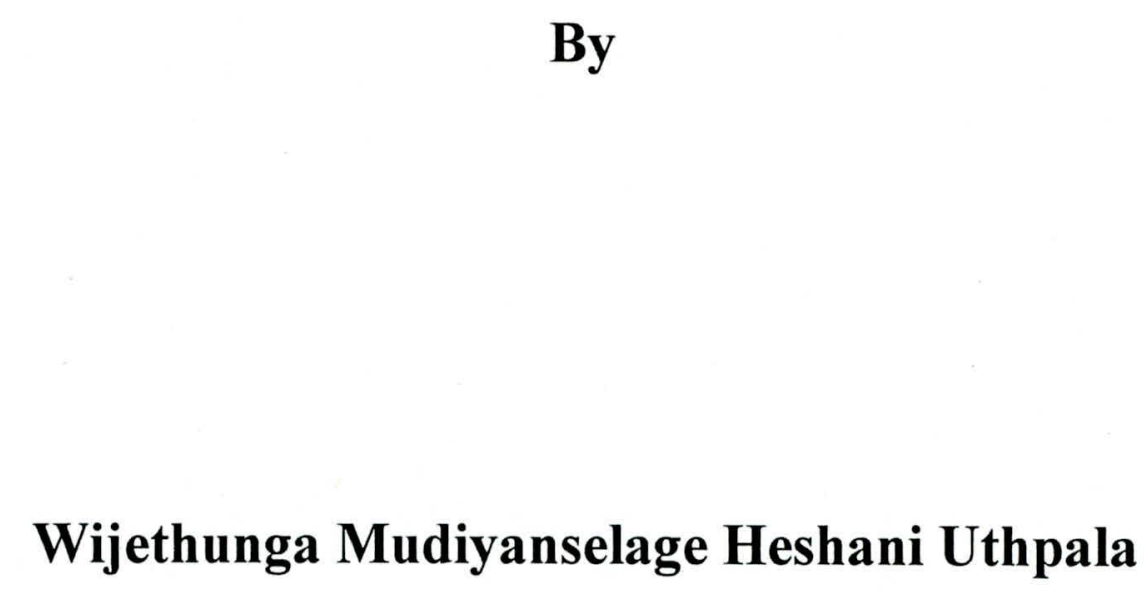

Wijethunga

A thesis submitted to the University of Sri Jayewardenepura in partial fulfillment of the requirements for the Degree of Master of Science in Management. 


\section{Declaration by the Candidate}

"The work described in this thesis was carried out by me under the supervision of Professor. B.N.F. Warnakulasooriya and a report on this has not been submitted in whole or in part to any university or any other institution for another Degree/Diploma".

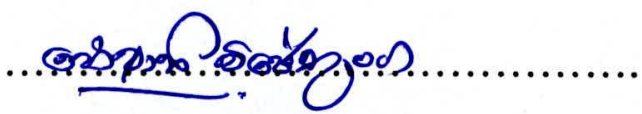

W.M.H.U.Wijethunga

M.Sc. Candidate 


\section{Declaration by the Supervisor}

"I certify that the above statement made by the candidate is true and that this thesis is suitable for submission to the university for the purpose of evaluation".

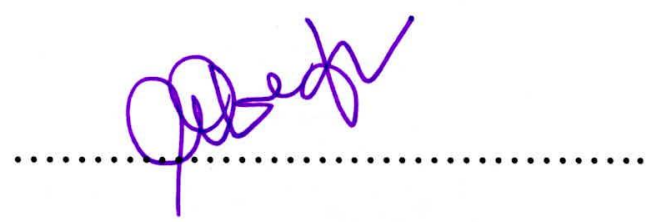

Date: ..301.05/20!5

Professor B.N.F. Warnakulasooriya

Supervisor 


\section{Table of Contents}

\begin{tabular}{|c|c|}
\hline Title & $\begin{array}{c}\text { Page } \\
\text { Number }\end{array}$ \\
\hline Table Contents & i-viii \\
\hline List of Tables & ix-xi \\
\hline List of Figures & xii \\
\hline Acknowledgements & xiii \\
\hline Abstract & xiv-xv \\
\hline Chapter 01 - Introduction to the Study & $1-11$ \\
\hline 01.1 Introduction to the Chapter & 1 \\
\hline 01.2 Background & $1-4$ \\
\hline 01.3 Research Problem & 4-6 \\
\hline 01.4 Research Questions & 6-7 \\
\hline 01.5 Objectives of the Study & 7 \\
\hline 01.6 Significance of the Study & $7-9$ \\
\hline 01.7 Scope of the Study & 9 \\
\hline 01.8 Limitations of the Study & $9-11$ \\
\hline 01.9 Chapter Summary & 11 \\
\hline
\end{tabular}




\begin{tabular}{|c|c|}
\hline Chapter 02- Literature Review & 12- 54 \\
\hline 02.1 Introduction to the Chapter & $12-13$ \\
\hline 02.2 Tourism and Tourist & $13-16$ \\
\hline 02.2.1 Tourism & $13-15$ \\
\hline 02.2.2 Tourist & $15-16$ \\
\hline 02.3 Motives & $16-27$ \\
\hline 02.3.1 Motivation definitions & $16-18$ \\
\hline 02.3.2 Motivation and Motives & $18-19$ \\
\hline 02.3.3 Approaches in Studying Tourist Motives & $20-27$ \\
\hline 02.3.2.1 Push and Pull Motives & $20-25$ \\
\hline $\begin{array}{l}\text { 02.3.2.2 Application of Maslow's Hierarchy of Needs } \\
\text { Theory in Tourism Research }\end{array}$ & $25-26$ \\
\hline 02.3.3 Segmenting the Market Using Travel Motivations & $26-27$ \\
\hline 02.4. Destination & $27-48$ \\
\hline 02.4.1 Defining Destination & $27-30$ \\
\hline 02.4.2 Actors Include in a Destination & $30-31$ \\
\hline 02.4.3 Destination Marketing & $31-32$ \\
\hline 02.4.4 Destination Image Perception & $32-48$ \\
\hline 02.4.4.1 Defining Image & $34-37$ \\
\hline 02.4.4.2 Features Describing the Image Construct & $37-38$ \\
\hline
\end{tabular}




\begin{tabular}{|c|c|}
\hline 02.4.4.3 Image and Image Perception & $38-43$ \\
\hline 02.4.4.4 Image Formation & $43-48$ \\
\hline $\begin{array}{l}\text { 02.5 Relationship between Tourist Motives and Destination Image } \\
\text { Perception }\end{array}$ & $48-50$ \\
\hline $\begin{array}{l}02.6 \text { Influence of Country of the Origin of the Tourists on the } \\
\text { Relationship between Image Perception and Tourist Motives }\end{array}$ & $51-54$ \\
\hline $\begin{array}{l}\text { 02.6.1 Importance of Considering the Country of the Origin of } \\
\text { the Tourists }\end{array}$ & $51-52$ \\
\hline 02.6.2 Country of the Origin and Culture & 52 \\
\hline $\begin{array}{l}\text { 02.6.3 Influence of the Country of the Origin of Tourists on } \\
\text { Tourist Motives and Image Perception }\end{array}$ & $53-54$ \\
\hline 02.7 Chapter Summary & 54 \\
\hline Chapter 03 - Research Design & $55-87$ \\
\hline 03.1 Introduction to the Chapter & 55 \\
\hline 03.2 Conceptual Framework & 55 \\
\hline 03.2.1 Tourist Motives & $56-58$ \\
\hline 03.2.2 Image Perception & $59-62$ \\
\hline 03.3 Research Questions & 62 \\
\hline 03.4 Hypotheses & $62-65$ \\
\hline 03.4.1 Hypothesis 01 & 63 \\
\hline 03.4.2 Hypothesis 02 & $63-64$ \\
\hline
\end{tabular}




\begin{tabular}{|c|c|}
\hline 03.4.3 Hypothesis 03 & 64 \\
\hline 03.4.4 Hypothesis 04 & 65 \\
\hline 03.5 Purpose of the Study & 66 \\
\hline 03.6 Type of Investigation & 66 \\
\hline 03.7 Extent of Researcher Interference & 67 \\
\hline 03.8 Study Setting & 67 \\
\hline 03.9 Unit of Analysis & 67 \\
\hline 3.10 Time Horizon & $67-68$ \\
\hline 03.11 Measurement and Measures & $68-72$ \\
\hline 03.11.1 Operationalization & 68 \\
\hline 03.11.1.1 Tourist Motives & 68 \\
\hline 03.11.1.2 Image Perception & 70 \\
\hline 03.11.2 Scaling & 72 \\
\hline 03.12 Sample Design & $72-73$ \\
\hline 03.12.1 Population & 72 \\
\hline 03.12.2 Sampling Unit and Sample Size & 72 \\
\hline 03.12.3 Sampling Design & $72-73$ \\
\hline 03.13 Data Collection Method & $73-74$ \\
\hline 03.13.1 Sources of Data & $73-74$ \\
\hline 03.13.2 Data Collection Method & 74 \\
\hline
\end{tabular}




\begin{tabular}{|c|c|}
\hline 03.14 Data Analyzing Techniques & 75 \\
\hline 03.15 Validation of Measurement Properties & $75-86$ \\
\hline 03.15.1 Content Validity & 76 \\
\hline 03. 15.2 Unidimensionality & $76-79$ \\
\hline 03. 15.3 Appropriateness of the Factor Analysis & 79 \\
\hline 03.15.4 Internal Consistency & $81-82$ \\
\hline 03.15.5 Convergent Validity & $82-84$ \\
\hline 03.15.6 Discriminant Validity & $85-86$ \\
\hline 03.16 Chapter Summary & $86-87$ \\
\hline Chapter 04 - Data Analysis & 88-134 \\
\hline 04.1 Introduction to the Chapter & 88 \\
\hline 04.2 Sample Profile & $88-89$ \\
\hline 04.2.1 Sample by Age & 90 \\
\hline 04.2.2 Sample by Gender & 91 \\
\hline 04.2.3 Sample by Country of Origin of Respondents & $91-92$ \\
\hline 04.2.4. Sample by Purpose of Visit & 93 \\
\hline 04.3 Basic Statistical Analyses & $93-99$ \\
\hline 04.4 Validation of Measurement Properties & $99-107$ \\
\hline 04. 4.1 Appropriateness of the Factor Analysis & $99-101$ \\
\hline
\end{tabular}




\begin{tabular}{|c|c|}
\hline 04.4.2 Internal Consistency & $101-103$ \\
\hline 04.4.3 Convergent Validity & $103-105$ \\
\hline 04.4.4 Discriminant Validity & $105-107$ \\
\hline 04.5 Hypothesis Testing & $107-133$ \\
\hline $\begin{array}{l}\text { 04.5.1 Salient Motive of the Tourists Arriving Sri Lanka is } \\
\text { Exiting Experience }\end{array}$ & $108-111$ \\
\hline $\begin{array}{l}\text { 04.5.2 Extent of Destination Image Perception on Sri Lanka as } \\
\text { a Tourist Destination }\end{array}$ & $111-114$ \\
\hline $\begin{array}{l}\text { 04.5.3 The Relationship between Tourist Psychological } \\
\text { Motives and Destination Image Perception of the } \\
\text { Tourists Who Select Sri Lanka as a Tourist Destination }\end{array}$ & $114-123$ \\
\hline 04.5.3.1 Scatter Plot Graph & $115-116$ \\
\hline 04.5.3.2 Scatter Plot Graph with Line of Best Fit & 117 \\
\hline 04.5.3.3 Correlational Analysis & $118-119$ \\
\hline 04.5.3.4 Bivariate Regression Analysis & $119-120$ \\
\hline 04.5.3.5 Examination of Residuals & 121 \\
\hline 04.5.3.6 Determining the Strength of the Association & 122 \\
\hline $\begin{array}{l}\text { 04.5.3.6 Determining the Significance of the } \\
\text { Association }\end{array}$ & 123 \\
\hline $\begin{array}{l}\text { 04.5.4 The Country of the Origin of Tourist Has a Moderating } \\
\text { Effect on the Relationship between Tourist Motives and } \\
\text { Image Perception }\end{array}$ & $124-133$ \\
\hline
\end{tabular}




\begin{tabular}{|c|c|}
\hline 04.5.4.1 Tourist Motives and Country of the Origin & 126 \\
\hline 04.5.4.2 Image Perception and Country of the Origin & 127 \\
\hline 04.5.4.3 Analysis Using Dummy Variable Regression & $127-129$ \\
\hline $\begin{array}{l}\text { 04.5.4.4 Test of Significance of Estimated Parameters of } \\
\text { the Dummy Variable Regression Model }\end{array}$ & $129-131$ \\
\hline 04.5.4.5 Determining the Strength of the Association & $131-132$ \\
\hline 04.5.4.6 Determining the Significance of the Association & $132-133$ \\
\hline 04.6 Chapter Summary & $133-134$ \\
\hline Chapter 05 - Discussion & 135-149 \\
\hline 05.1 Introduction to the Chapter & 135 \\
\hline 05.2 Salient Motives of Tourists to Sri Lanka as a Tourist Destination & $135-139$ \\
\hline $\begin{array}{l}\text { 05.3 Extent of Tourist Image Perception on Sri Lanka as a Tourist } \\
\text { Destination }\end{array}$ & $139-142$ \\
\hline $\begin{array}{l}\text { 05.4 The Relationship between Tourist Psychological Motives and } \\
\text { Destination Image Perception of the Tourists Who Select Sri } \\
\text { Lanka as a Tourist Destination }\end{array}$ & $142-144$ \\
\hline $\begin{array}{c}\text { 05.5 The Country of the Origin of Tourist Has a Moderating Effect on } \\
\text { the Relationship between Tourist Motives and Image Perception }\end{array}$ & $144-148$ \\
\hline 05.6 Chapter Summary & $148-149$ \\
\hline
\end{tabular}




\begin{tabular}{|l|c|}
\hline Chapter 06 - Summary and Conclusion & $150-156$ \\
\hline 06.1 Introduction to the Chapter & 150 \\
\hline 06.2 Summary & $150-153$ \\
\hline 06.3 Conclusion & $153-156$ \\
\hline 06.4 Chapter Summary & 156 \\
\hline & \\
\hline Appendixes & \\
\hline Appendix 01 - Questionnaire 01 & \\
\hline Appendix $02-$ Questionnaire 02 & \\
\hline
\end{tabular}




\section{List of Tables}

\begin{tabular}{|l|c|}
\hline \multicolumn{1}{|c|}{ Table Title } & Page Number \\
\hline Table 3.1: Items of Motive Dimensions & 69 \\
\hline Table 3.2: Items of Image Perception Dimensions & $70-71$ \\
\hline Table 3.3: Factor Loading of Tourists' Motives Items & 77 \\
\hline Table 3.4: Factor Loading of Image Perception Items & 78 \\
\hline Table 3.5: Validity Indexes & 80 \\
\hline Table 3.6: Internal Consistency Statistics & 82 \\
\hline Table 3.7: Convergent Validity & 84 \\
\hline Table 3.8: Discriminant Validity of Image Perception Construct & 85 \\
\hline Table 3.9: Discriminant Validity of Tourist Motives Construct & 86 \\
\hline Table 4.1: Summary of the Sample Profile & 89 \\
\hline Table 4.2: Sample by Age & 90 \\
\hline Table 4.3: Sample by Gender & 93 \\
\hline Table 4.4: Sample by Country of the Origin of Respondents & 96 \\
\hline Table 4.5: Sample by Purpose of Visit & 93 \\
\hline Table 4.6: Decision Criteria in Assessing the Normal Distribution & 96 \\
\hline Table 4.7: Results of Univariate Normal Distribution Test: & \\
\hline Dimensions of Tourist Motives & \\
\hline Dable 4.8: Results of Univariate Normal Distribution Test: & 93 \\
\hline
\end{tabular}




\begin{tabular}{|c|c|}
\hline Table 4.9: Validity Indexes & 100 \\
\hline Table 4.10: Internal Consistency Statistics & 102 \\
\hline Table 4.11: Convergent Validity & 104 \\
\hline Table 4.12: Discriminant Validity of Image Perception Construct & 106 \\
\hline Table 4.13: Discriminant Validity of Tourist Motives Construct & 107 \\
\hline Table 4.14: Statistical Tool to Test the Hypothesis & 108 \\
\hline Table 4.15: Mean Scores - Dimensions of Tourist Motives & 109 \\
\hline Table 4.16: Paired Sample t-Test & 110 \\
\hline $\begin{array}{l}\text { Table 4.17: Mean Values of the Dimensions of the Image } \\
\text { Perception }\end{array}$ & 112 \\
\hline Table 4.18: Decision Criteria-Degree of Image Perception & 112 \\
\hline Table 4.19: One Sample T-test & 113 \\
\hline $\begin{array}{l}\text { Table 4.20: Correlations of Tourist Push Motives and Image } \\
\text { Perception }\end{array}$ & 118 \\
\hline $\begin{array}{l}\text { Table 4.21: Coefficients of Tourist Push Motives and Image } \\
\text { Perception }\end{array}$ & 119 \\
\hline $\begin{array}{l}\text { Table 4.22: Coefficient Determination for Tourist Motives and } \\
\text { Image Perception }\end{array}$ & 122 \\
\hline Table 4.23: Analysis of Variance - F Statistic & 123 \\
\hline $\begin{array}{l}\text { Table 4.24: Mean Values of Tourist's Motives and Mean Values } \\
\text { Image Perception by the Country of the Origin of } \\
\text { Tourists }\end{array}$ & 125 \\
\hline
\end{tabular}




\begin{tabular}{|c|c|}
\hline $\begin{array}{c}\text { Table 4.25: Association between the Country of Origin and } \\
\text { Tourist Motives - ANOVA }\end{array}$ & 126 \\
\hline $\begin{array}{l}\text { Table 4.26: Association between the Country of Origin and Image } \\
\text { Perception - ANOVA }\end{array}$ & 127 \\
\hline Table 4.27: Dummy Variables & 128 \\
\hline Table 4.28: Coefficients of Tourist Motives and Image Perception & 129 \\
\hline $\begin{array}{l}\text { Table 4.29: Coefficients of Dummy Variables and the Interaction } \\
\text { Terms }\end{array}$ & 130 \\
\hline Table 4.30: Results of Coefficient of Determination & 131 \\
\hline Table 4.31: ANOVA- F statistic & 132 \\
\hline
\end{tabular}




\section{List of Figures}

\begin{tabular}{|l|c|}
\hline \multicolumn{1}{|c|}{ Figure Title } & Page \\
& Number \\
\hline Figure 3.1: Conceptual Framework & 55 \\
\hline Figure 4.1 Scatter Plot of Tourist (Push) Motives and Image Perception & 116 \\
\hline Figure 4.2: Scatter Plot Graph with Line of Best Fit - Tourist (Push) \\
Motives and Image Perception & 117 \\
\hline Figure 4.3: Normality Plot of Residuals & 121 \\
\hline
\end{tabular}




\section{Acknowledgements}

Profferssor. B.N.F. Warnakulasooriya, for his tremendous guidance, patience and his unique teaching style. Dear Sir, please accept my gratitude towards the guidance you provided, time and effort you have exerted and thank you for the exposure and insights you have given on the arena of research.

Next, I would like to thank Mr. N. Agilan (Lecturer, University of Peradeniya), Mr. Kamal and his staff (Cultural Center, Knady) for the genuine support that has provided; and the time and effort extended towards my research work.

Finally, my gratitude is for my supportive family; my mother, father, husband, sister and brother for the understanding, patience and all the assistance provided to achieve this difficult task. Without all of you, the final outcome of my effort will not be a success. 


\title{
Tourist Motives and Destination Image Perception: The Case of Sri
}

\author{
Lanka as a Tourist Destination
}

\section{Wijethunga Mudiyanselage Heshani Uthpala Wijethunga}

\begin{abstract}
\end{abstract}
Tourism as a growing industry constitutes a major contributor to the Gross Domestic Product in Sri Lanka and draws high priority status in the government's policy initiatives. However, the emergence of new destinations worldwide has opened new avenues for potential tourists to choose a destination to match with their interests and motivation. The image held by travelers on a specific tourist destination is of high influencer to select alternative tourist destinations. Majority of past researches have integrated image perception with external stimuli, by ignoring the influence of internal factors such as psychological motives and tourist's country of the origin. The objectives of the present study are to identify salient motives of tourists; to assess the extent of image perception of tourists to Sri Lanka; to test the association between tourist motives and destination image perception of the tourists who select Sri Lanka as a tourist destination and finally to study whether the association between tourist's motives and image perception is moderated by the tourists' country of the origin. Single cross sectional research design was employed to collect data through a self administered questionnaire. The unit of analysis and the proxies are the international tourists to Sri Lanka. A sample of 290 international tourists, who came to Sri Lanka during January to August, 2014 was selected. First, an exploratory factor analysis with 
Varimax rotation was performed to examine whether the originally developed indicators are converged on the respective dimensions of each construct. Next, paired sample t-test and one sample t-test were carried out to measure the first two hypotheses while regression analysis and regression analysis with dummy variables have been performed to test the last two hypotheses respectively. The analysis shows that the destination image perception on Sri Lanka is not a favorable one, rather neutral and further novelty, knowledge, escape and relationship strengthening are the salient motives of the tourists to Sri Lanka. Moreover, it is found that there is a weak positive relationship between Tourist's Motives and Image Perception; and there is a moderating impact by the country of origin to the relationship between Tourist's Motives and Image Perception. The implication of this research can be used to develop the tourist marketing mix to suit the image perception of tourists and to segment the destination market basing on tourist motives.

Key words: Country of the Origin, Destination, Image perception, International Tourists, Tourist Motives 